\title{
Relationships between physiological and behavioral responses of goat bucks in mating season
}

\author{
Serhat Karaca' ${ }^{1}$, Ayhan Yılmaz², Gazel Ser ${ }^{1}$, Muammer Sarıbey $^{1}$
}

\footnotetext{
1 Yuzuncu Yil University, Faculty of Agriculture, Department of Animal Science, Van, Turkey.

${ }^{2}$ Siirt University, Department of Animal Science, Siirt, Turkey.
}

\begin{abstract}
The objective of this study was to determine the sexual parameters in young bucks with different sexual activity and the effect of experience (age) on sexual parameters in bucks. Fifteen young, sexually inexperienced (SI) and five adult, sexually experienced (SE) Saanen $\times$ Hair goat crossbred bucks were used in this study. Bucks were individually exposed to three estrus does for 15-min periods during four sexual performance tests, which were carried out every other day to determine some sexual behavior traits such as flehmen response, reaction time, and ejaculation efficiency. Sexually inexperienced young bucks were evaluated based on their sexual activity (active (AC) vs inactive (IA)) and presence of horn. It was found that $\mathrm{AC}$ bucks had significantly higher serum testosterone concentrations ( $31.5 \mathrm{vs} 21.5 \mathrm{ng} / \mathrm{mL})$ and weight loss (114.2 vs $51.2 \mathrm{~g} /$ day) than IA bucks. In addition, weight loss was significantly correlated with ejaculation efficiency in young bucks. On the other hand, horned bucks tended to have higher ejaculation efficiency with significantly longer reaction time than polled bucks. For experience (age) classes, SE bucks had higher testosterone concentration (76.0 vs $31.5 \mathrm{ng} / \mathrm{mL}$ ) and weight loss (16.7 vs 8.6\%) than SI active young bucks. However, the effect of experience on other sexual performance traits was found to be limited. Overall, these results indicate that testosterone concentration may affect sexual performance of young bucks in the mating season. Age-related sexual experience is not a determining factor for sexual performance in bucks. However, sexual performance data alone may not reflect reproductive outcomes without semen data.
\end{abstract}

Key Words: copulation, experience, reaction time, test-day, testosterone

\section{Introduction}

The sexual behavior of goats is an important factor for flock breeding efficiency and productivity in goat farming. Male fertility is a vital issue because numerous does are generally mated to a single buck. On the other hand, if sexual behaviors are expressed and semen is collected at earlier ages, these could be used in breeding programs to shorten the generation interval. Therefore, evaluation of male fertility using a serving capacity test prior to mating is good practice to reach breeding success.

In goat bucks, courting (latency and amount of courting anogenital sniffing, vocalization, nudging, and flehmen) and copulatory (mounting and ejaculation) behaviors are evaluated using a sexual performance test that is part of a serving capacity test (Imwalle and Katz, 2004; Darwish and Mahboub, 2011).

Received 21 April, 2016 and accepted August 4, 2016

Corresponding author: serhatkaraca@gmail.com

http://dx.doi.org/10.1590/S1806-92902016001000005

Copyright (C) 2016 Sociedade Brasileira de Zootecnia. This is an Open Access article distributed under the terms of the Creative Commons Attribution License (http://creativecommons.org/licenses/by/4.0/), which permits unrestricted use, distribution, and reproduction in any medium, provided the original work is properly cited.
Serving capacity and sexual performance tests can be used to predict pasture-mating efficiency in rams (Perkins and Roselli, 2007). However, these types of test are not common practices for small ruminants and there is less interest and fewer studies associated with sexual performance in goats compared with other livestock species (Flores et al., 2000; Darwish and Mahboub, 2011; Moghaddam et al., 2012).

Testosterone concentration is known to affect spermatogenesis, the expression of sexual behavior, and secondary sexual traits (Roselli et al., 2002; Perkins and Roselli, 2007). However, the factors affecting the variation in peripheral testosterone concentration are not well understood. Moreover, few studies have been conducted to determine the variation of testosterone concentration and its relationship with sexual performance of young males in mating season (Preston et al., 2012).

A positive relationship between presence of horn and semen characteristics has been reported (Al-Ghalban et al., 2004). Better fertility results were observed when horned bucks were used (Rekik et al., 2012). However, the effect of presence of horn on sexual performance needs clarification.

Sexual performance can vary depending on experience, age, and time of first exposure to estrus female (Perkins and 
Roselli, 2007). Previous studies have indicated that older males had higher ejaculation efficiency (Kridli and Said, 1999; Price et al., 1991) and shorter reaction time (Darwish and Mahboub, 2011) than younger rams and bucks.

The present study was undertaken to determine the sexual parameters (sexual performance test findings, testosterone concentrations, and scrotal circumference) in young bucks with different sexual activity and the effect of experience (age) on sexual parameters in bucks.

\section{Material and Methods}

The study was carried out on an experimental

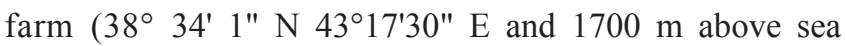
level) located in the city of Van, in 2014. Van is a city in the eastern region of Turkey with a harsh continental climate of cold, snowy winters and warm, dry summers (Peel et al., 2007). During the period in which the study was conducted, the average air temperature was $17^{\circ} \mathrm{C}$ and average monthly precipitation was $14.3 \mathrm{~kg} / \mathrm{m}^{2}$ according to long-term meteorological data (1950-2015) (Anonymous, 2016). The animal material used in the study consisted of 15 sexually inexperienced (SI; with an average age of 1.5 years; first service season) and five sexually experienced (SE; with an average age of 3.8 years; $\geq$ two service seasons) Saanen $\times$ Hair goat crossbred bucks; and 12 Hair goat does (with an average age of 4.1 years). All bucks (five adult + fifteen young) were exposed to 120 does in total. Polled:Horned ratio was 8:7 for inexperienced bucks and 3:2 for adult bucks. Goats grazed on pasture two times a day for eight hours (from $06.00 \mathrm{~h}$ to $10.00 \mathrm{~h}$ and from $15.00 \mathrm{~h}$ to $19.00 \mathrm{~h}$ ) and for the rest of the day they were penned with no extra feed supplementation. Species existing in the native pasture were 22 species of Poaceae (Aegilops spp, Bromus spp, and others.), 25 species of Fabaceae (Astragalus spp, Vicia spp, Trifolium spp, Medicago spp, Lotus corniculatus, and others), 17 Asteraceae, eight Caryophyllaceae, five Cyperaceae, and 16 other species.

The experiment was carried out at the onset of the breeding season (from September 1st to 30th, 2014). During this period of time, all bucks were with the does, except on the days on which sexual performance tests were performed. Four sexual performance tests were carried out in the middle of September (from September 13th to 19th) as described by Price (1993). Visual and olfactory contacts between bucks and does were prevented before the sexual performance tests. Tests were carried out in a $4 \times 5 \mathrm{~m}$ area by penning bucks individually with three unrestrained estrous does for $15 \mathrm{~min}$. Testing was conducted every other day and carried out between $07.00 \mathrm{~h}$ and $13.00 \mathrm{~h}$. The bucks to be tested were selected randomly to eliminate the effect of the day. All bucks were tested for the flehmen response (FR), latency to first mount (FM: the time from entry into the pen to the first mount), number of mounts (nM: attempts to mount or mount without pelvic oscillation), reaction time (RT: the time between the exposure of a male to estrus female and ejaculation), number of ejaculations (nE), and ejaculation efficiency (EE). Ejaculation efficiency was calculated as follows: Ejaculation efficiency $=$ mounts with ejaculations / (mounts with ejaculations + mounts without ejaculations). Sexual behavior was observed by two researchers; one researcher monitored the behavior traits while the other recorded the data.

After sexual performance tests, young bucks were divided into two sexual activity groups as active or inactive. Based on Perkins et al. (1992), bucks which mounted at least ten times and had one ejaculation during the last two tests were classified as active bucks. For experience (age) analysis, the old, sexually experienced (SE) bucks were compared with young, active, sexually inexperienced (SI) bucks.

The presence or absence of horns was recorded for each buck. Only inexperienced bucks were used to determine the effect of presence of horn. The body weights of animals were recorded at the beginning and end of the experiment (from September 1st to 30th, 2014). At the beginning of the study, scrotal circumference $(\mathrm{cm})$ was measured with a flexible tape placed around the scrotum.

Testosterone concentrations (TC) of bucks were determined by using blood samples that were collected twice on the same day (on the same day as body weight measurements) from vena jugularis of each buck. On each sampling day, $10 \mathrm{~mL}$ blood was collected at $07.00 \mathrm{~h}$ and $17.00 \mathrm{~h}$. The blood samples were centrifuged at $3000 \times \mathrm{g}$ for $15 \mathrm{~min}$, then serum was harvested and stored at $-80{ }^{\circ} \mathrm{C}$ until assayed. Serum testosterone concentrations were assayed by using a goat testosterone commercial ELISA kit (CSB-E13630G, Cusabio Biotech Co. Ltd., Wuhan, China) according to the manufacturer's instructions. The detection range of the kit is $0.1-20.0 \mathrm{ng} / \mathrm{mL}$ and sensitivity is $0.05 \mathrm{ng} / \mathrm{mL}$. Coefficient of variation of the kit is below $15 \%$. The samples with higher testosterone concentration than the highest standard were diluted with phosphatebuffered saline.

Data were analyzed using the SPSS 22.0 software to determine the effects of sexual activity, presence of horn, experience (age), and test-day as the main factors affecting sexual behavior traits, body measurements, and testosterone 
concentrations. The normality tests of all variables were performed with the Shapiro-Wilk test. The variables that had non-normal distribution such as FR, FM, nM, RT, nE, and EE were analyzed by Mann-Whitney U and KruskalWallis $\mathrm{H}$ tests. Testosterone concentrations of bucks were analyzed by the General Linear Model method using the following equation:

$$
\mathrm{Y}_{\mathrm{ijkl}}=\mu+\alpha_{\mathrm{i}}+\beta_{\mathrm{j}}+\tau_{\mathrm{k}}+\mathrm{e}_{\mathrm{ijkl}},
$$

in which $\mathrm{Y}_{\mathrm{ijkl}}=$ the value of the examined characteristic for the $l$-th animal in the $k$-th sampling time and the $j$-th sampling day from $i$-th sexual activity, experience (age), and presence of horn; $\mu=$ overall mean; $\alpha_{i}=$ the fixed effect of sexual activity (active or inactive), experience (age) (experienced or inexperienced), and presence of horn (horned or polled); $\beta_{\mathrm{j}}=$ fixed effect of sampling day (initial day or final day); $\tau_{\mathrm{k}}=$ fixed effect of sampling time (morning or evening); and $\mathrm{e}_{\mathrm{ijkl}}=$ random error.

Body weights and scrotal circumference of bucks were analyzed with the independent samples t-test. Spearman rank correlation coefficient was used to determine the relationships among traits. In addition to this, multiple correspondence analysis was used to represent projection of the relationship among categorical variables. The categorization of the testosterone concentration and live weight loss were carried out according to frequency distributions of these variables.

\section{Results}

After sexual performance tests, it was determined that young bucks displaying low sexual activity accounted for approximately $50 \%$ of all young bucks. There were no significant differences between active (AC) and inactive (IA) yearling bucks in terms of body weight and scrotal circumference. On the other hand, TC, live weight loss, and sexual performance traits were significantly different between $\mathrm{AC}$ and IA young bucks $(\mathrm{P}<0.05)$ (Tables 1 and 2 ). There were no significant differences between horned and polled bucks in terms of physical traits and serum testosterone concentrations (Table 1).

The findings of serum testosterone analysis showed that AC bucks had significantly higher testosterone concentrations than IA bucks, while testosterone concentrations did not significantly vary according to sampling time $(\mathrm{P}=0.419)$ (Figure 1).

The expressions of sexual behavior throughout sexual performance testing were found to be significantly different between AC and IA bucks. It can be seen that AC bucks had higher FR, nM, nE, and EE than IA ones (Table 2). On the other hand, FM and RT were low in polled bucks, whereas the EE tended to be higher in horned young bucks in the present study.

Table 1 - Body weight changes, scrotal circumference (mean \pm SE) and serum testosterone concentrations (Least square mean \pm SEM) of young bucks according to sexual activity and presence of horns

\begin{tabular}{|c|c|c|c|c|c|c|}
\hline \multirow{2}{*}{ Trait } & \multicolumn{2}{|c|}{ Sexual activity } & \multirow{2}{*}{ P-value } & \multicolumn{2}{|c|}{ Presence of horns } & \multirow{2}{*}{ P-value } \\
\hline & Active & Inactive & & Polled & Horned & \\
\hline Number of bucks & 8 & 7 & & 8 & 7 & \\
\hline Scrotal circumference $(\mathrm{cm})$ & $25.7 \pm 0.76$ & $25.6 \pm 0.64$ & 0.924 & $26.3 \pm 0.79$ & $25.1 \pm 0.56$ & 0.243 \\
\hline Initial body weight (kg) & $38.3 \pm 0.91$ & $37.3 \pm 1.36$ & 0.572 & $37.1 \pm 0.94$ & $38.6 \pm 1.22$ & 0.342 \\
\hline Final body weight (kg) & $35.0 \pm 0.89$ & $35.9 \pm 1.05$ & 0.527 & $35.1 \pm 0.59$ & $35.7 \pm 1.18$ & 0.696 \\
\hline Weight loss $(\%)$ & $8.6 \pm 0.84$ & $3.7 \pm 1.74$ & 0.020 & $5.0 \pm 1.73$ & $7.5 \pm 1.37$ & 0.266 \\
\hline Daily weight loss (g) & $114.2 \pm 10.80$ & $51.23 \pm 23.82$ & 0.026 & $66.5 \pm 22.60$ & $100.9 \pm 18.67$ & 0.257 \\
\hline Serum testosterone $(\mathrm{ng} / \mathrm{mL})^{1}$ & $31.5 \pm 3.26$ & $21.5 \pm 3.49$ & 0.038 & $27.7 \pm 3.65$ & $26.1 \pm 3.41$ & 0.740 \\
\hline
\end{tabular}

SE - standard error; SEM - standard error of the mean.

${ }^{1}$ Average of sampling days.

Table 2 - Sexual performance (mean \pm SE) of young bucks according to sexual activity and presence of horns

\begin{tabular}{|c|c|c|c|c|c|c|}
\hline \multirow{2}{*}{ Trait $^{1}$} & \multicolumn{2}{|c|}{ Sexual activity } & \multirow{2}{*}{ P-value } & \multicolumn{2}{|c|}{ Presence of horns } & \multirow{2}{*}{ P-value } \\
\hline & Active & Inactive & & Polled & Horned & \\
\hline Number of observations & 32 & 28 & & 32 & 28 & \\
\hline Flehmen response & $2.9 \pm 0.30$ & $1.7 \pm 0.30$ & 0.007 & $2.0 \pm 0.32$ & $2.6 \pm 0.30$ & 0.154 \\
\hline Latency to first mount (min) & $2.0 \pm 0.56$ & $1.9 \pm 1.09$ & 0.783 & $0.6 \pm 0.22$ & $2.5 \pm 0.67$ & 0.031 \\
\hline Number of mounts & $15.5 \pm 3.00$ & $5.3 \pm 2.32$ & $<0.001$ & $5.0 \pm 1.56$ & $15.7 \pm 3.33$ & 0.001 \\
\hline Reaction time (min) & $3.5 \pm 0.75$ & $5.5 \pm 1.31$ & 0.095 & $1.4 \pm 0.31$ & $5.0 \pm 0.83$ & 0.006 \\
\hline Number of ejaculations & $1.0 \pm 0.17$ & $0.2 \pm 0.09$ & $<0.001$ & $0.6 \pm 0.20$ & $0.7 \pm 0.11$ & 0.117 \\
\hline Ejaculation efficiency & $0.18 \pm 0.045$ & $0.03 \pm 0.019$ & $<0.001$ & $0.08 \pm 0.038$ & $0.14 \pm 0.038$ & 0.052 \\
\hline
\end{tabular}

SE - standard error.

${ }^{1}$ Average values of sexual behaviors in four tests. 
Highly significant correlations were found between body weight loss and some sexual performance traits (Table 3). Flehmen response, $\mathrm{nM}$, and $\mathrm{nE}$ were significantly correlated with weight loss $(\mathrm{P}<0.001)$ (Table 3$)$. In other words, as sexual activity of bucks increased the loss in live weight increased. There was a significant correlation between scrotal circumference and testosterone concentration $(\mathrm{P}<0.05)$.

Two dimensions explained $57.1 \%$ of the total variation defined by multiple correspondence analysis. The first dimension explained $38.3 \%$ of total variation. Sexual activity was correlated with being horned, higher weight loss (\%), testosterone concentration, and libido, i.e., AC bucks are located on the right side of the first dimension. The second dimension explained $18.8 \%$ of variability and was characterized by Test 1, 3, and serum testosterone concentrations (Figure 2).

It was determined that SE bucks had higher live weight loss than SI bucks during the experiment (Table 4). SE bucks had higher serum testosterone concentrations than SI bucks, indicating that testosterone concentrations were

Table 3 - Significant Spearman rank correlation coefficients $\left(r_{s}\right)$ between sexual behavior and scrotal circumference and testosterone concentration in young bucks

\begin{tabular}{lrr}
\hline Trait & $\mathrm{r}_{\mathrm{s}}$ & P-value \\
\hline Scrotal circumference - testosterone concentration & 0.264 & 0.041 \\
Flehmen response - weight loss & 0.481 & $<0.001$ \\
Number of mounts - weight loss & 0.496 & $<0.001$ \\
Number of ejaculations - reaction time & -0.655 & $<0.001$ \\
Number of ejaculations - flehmen response & 0.395 & 0.002 \\
Number of ejaculations - weight loss & 0.537 & $<0.001$ \\
Number of ejaculations - number of mounts & 0.487 & $<0.001$ \\
Ejaculation efficiency - weight loss & 0.500 & $<0.001$ \\
\hline
\end{tabular}

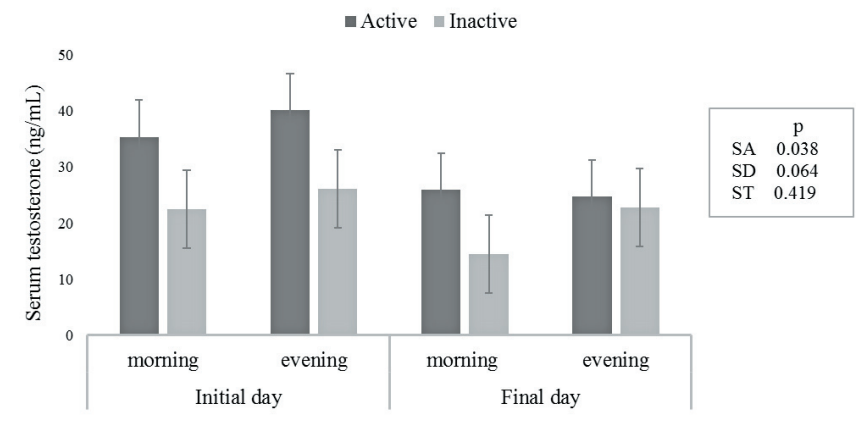

SEM - standard error of the mean.

Figure 1 - Serum testosterone concentrations (least square mean \pm SEM) determined at different sampling times (ST; morning vs afternoon) of sampling days (SD; initial vs final day) in young bucks having different sexual activity (SA; active vs inactive). significantly affected by age. However, TC did not differ according to sampling day or time (Figure 3).

The results of the sexual performance tests in the present study showed that experience had no significant effect on sexual behavior traits, except FR (Table 5).

Table 4 - Body weight changes, scrotal circumference (mean $\pm \mathrm{SE}$ ) and serum testosterone concentrations (least square mean \pm SEM) in sexually inexperienced (first service season) and experienced ( $\geq 2$ service seasons) bucks

\begin{tabular}{lccc}
\hline Trait & $\begin{array}{c}\text { Inexperienced } \\
\text { bucks }^{1}\end{array}$ & $\begin{array}{c}\text { Experienced } \\
\text { bucks }\end{array}$ & P-value \\
\hline Number of bucks & 8 & 5 & \\
Scrotal circumference $(\mathrm{cm})$ & $25.7 \pm 0.76$ & $29.3 \pm 1.89$ & $<0.001$ \\
Initial body weight $(\mathrm{kg})$ & $38.3 \pm 0.91$ & $70.5 \pm 5.04$ & $<0.001$ \\
Final body weight $(\mathrm{kg})$ & $35.0 \pm 0.89$ & $58.8 \pm 4.86$ & $<0.001$ \\
Weight loss $(\%)$ & $8.6 \pm 0.84$ & $16.77 \pm 1.03$ & $<0.001$ \\
Testosterone $(\mathrm{ng} / \mathrm{mL})^{2}$ & $31.5 \pm 5.86$ & $76.0 \pm 7.42$ & $<0.001$ \\
\hline
\end{tabular}

SE - standard error.

${ }^{1}$ Only sexually active young bucks were evaluated.

${ }^{2}$ Average of sampling days.

Table 5 - Sexual performance (mean \pm SE) of sexually inexperienced (first service season) and experienced ( $\geq 2$ service seasons) bucks

\begin{tabular}{lccr}
\hline Trait $^{1}$ & $\begin{array}{c}\text { Inexperienced } \\
\text { bucks }^{2}\end{array}$ & $\begin{array}{c}\text { Experienced } \\
\text { bucks }\end{array}$ & P-value \\
\hline Number of observations & 32 & 20 & \\
Flehmen response & $2.9 \pm 0.30$ & $0.9 \pm 0.19$ & $<0.001$ \\
Latency to first mount (min) & $2.0 \pm 0.56$ & $1.9 \pm 0.75$ & 0.992 \\
Number of mounts & $15.5 \pm 3.00$ & $17.3 \pm 2.83$ & 0.301 \\
Reaction time (min) & $3.5 \pm 0.75$ & $4.3 \pm 1.08$ & 0.521 \\
Number of ejaculations & $1.0 \pm 0.17$ & $1.2 \pm 0.19$ & 0.402 \\
Ejaculation efficiency & $0.18 \pm 0.045$ & $0.10 \pm 0.022$ & 0.531 \\
\hline
\end{tabular}

SE - standard error

${ }^{1}$ Average values of sexual behaviors in four tests.

${ }^{2}$ Only sexually active young bucks were evaluated.

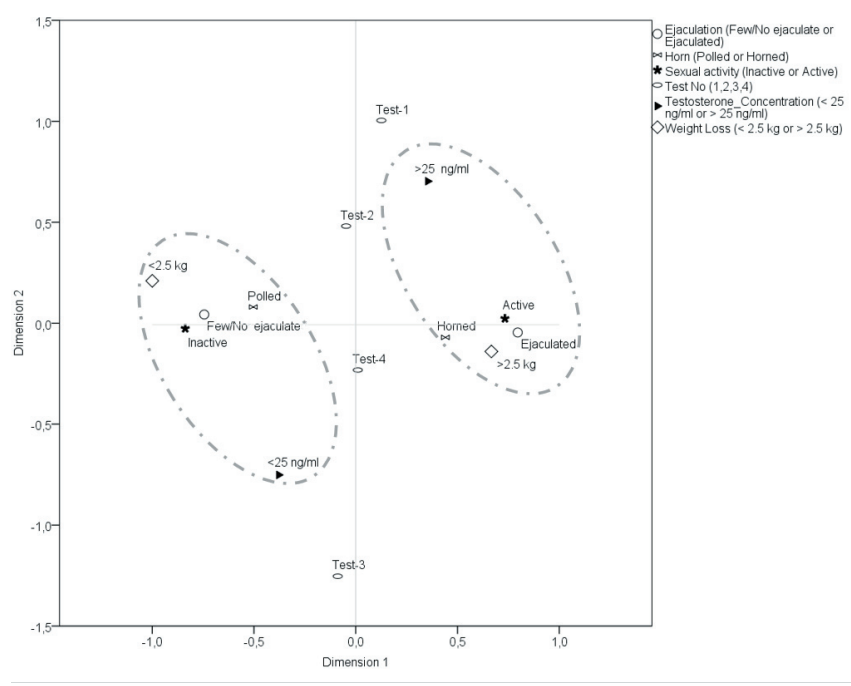

Figure 2 - Multiple correspondence analysis for some physiological and behavioral variables of young bucks. 


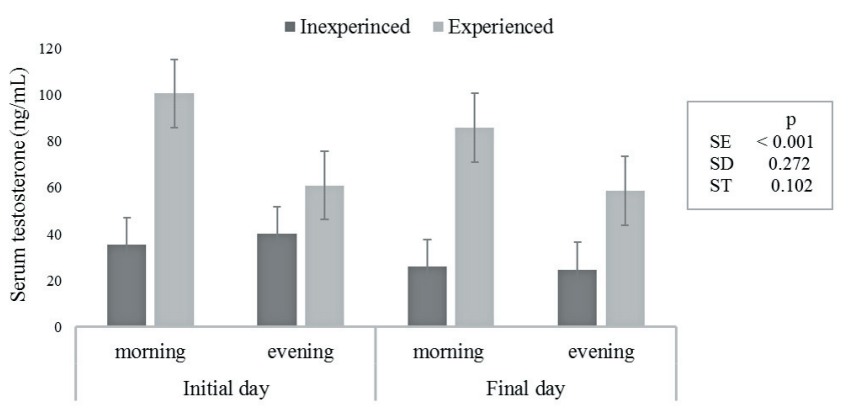

SEM - standard error of the mean.

Figure 3 - Serum testosterone concentrations (least square mean \pm SEM), determined at different sampling times (ST; morning vs afternoon) of sampling days (SD; initial vs final day) in bucks having different sexual experience (SE; experienced vs inexperienced).

\section{Discussion}

The live weight loss of bucks depends on various factors such as feed supply and climatic conditions, mating places, buck to doe ratio, and individual variations in sexual activity in the mating season. The differences between live weight loss of AC and IA young bucks observed in the present study might be associated with sexual activity (Table 1). A previous study demonstrated that there was a positive relationship between weight loss and number of servings during the peak of the mating period (Gizaw and Thwaites, 1997).

In general, horned goats were reported to be heavier and more aggressive than polled goats and to dominate them (Miranda-de la Lama and Mattiello, 2010). In addition, fertility improved when using horned rather than polled bucks during the breeding season (Al-Ghalban et al., 2004; Rekik et al., 2012). However, the findings of the present study showed that the presence of horn did not significantly affect body weight, scrotal circumference, and TC (Table 1). It appears that the relationships between being horned and scrotal circumference and TC are not clearly seen in sexual performance traits at younger ages. Since all horned bucks were not sexually active, TC was found to be insignificant.

It is well known that serum testosterone concentrations, semen characteristics, and sexual activity could vary depending on season. It has been reported that testosterone concentrations and sexual performance are significantly high in the mating season (Ahmad and Noakes, 1995; Souri and Mirmahmoudi, 2014). On the other hand, some studies focused only on the variation of sexual performance and its relationship with testosterone concentrations in the mating season (Perkins et al., 1992). Perkins et al. (1992) reported that testosterone concentrations of rams with high sexual performance were higher than rams with low performance in the mating season. In agreement with this study, it was observed that AC bucks had significantly higher serum testosterone levels in comparison with IA bucks (Table 1 and Figure 1) and AC bucks tended to have shorter RT than IA bucks (3.5 vs $5.5 \mathrm{~min})(\mathrm{P}=0.095)$. Previous studies reported that the reduction in RT with increase in testosterone concentrations (Kishk, 2008; Karaca et al., 2015) and elevated testosterone concentrations (Borg et al., 1992) tended to be associated with courtship behaviors.

During the trial, bucks were with does and mating was continuing. So, it appears that copulation activity during the breeding season had a slight effect on testosterone levels of bucks. Therefore, TC tended to decrease on the final day compared with the initial day of the trial $(\mathrm{P}=0.064)$ (Figure 1). Preston et al. (2012) and Dufour et al. (1984) reported that testosterone levels in rams were high at the beginning of the mating season, and then declined through the course of the mating season. However, Illius et al. (1976) reported that the testosterone profiles of young rams were not affected by copulation.

Although Perkins and Roselli (2007) reported that some sexually inactive rams would begin to copulate if provided with additional opportunities, the results of the present study demonstrated that sexual performance tests did not improve the sexual activity of young bucks $(\mathrm{P}=0.427)$ (data are not given). This finding is in line with the finding that bucks do not require sexual experience with estrus females to reach complete serving capacity (Price et al., 1998). However, Imwalle and Katz (2004) suggested that additional opportunities are useful to learn important cues from does to improve sexual experience. Similar findings were indicated by other researchers for rams (Snowder et al., 2002; Stellflug and Berardinelli, 2002). Various factors were reported to affect the findings of sexual performance tests such as sexual motivation, experience, separation anxiety, sexual attractiveness of partner, length of testing period, etc. (Snowder et al., 2002; Imwalle and Katz, 2004). In the present study, it was observed that some of the IA young bucks displayed separation anxiety when removed from pen mates to the test site. In addition, three of the IA young bucks never mounted does. Similar findings reported that $28-40 \%$ of yearlings that had no previous sexual experience were sexually inactive during the first test with estrus females (Price et al., 1994; Snowder et al., 2002).

The findings of the present study reveal that the sexual motivation of AC bucks was underlined by higher FR, $\mathrm{nM}$ and $\mathrm{nE}, \mathrm{EE}$, and TC (Table 2). These results are in line with findings of Perkins et al. (1992). A number of 
studies have illustrated that several factors such as breed, climatic conditions, and individual differences affect sexual performance in bucks. In tropical conditions, for example, a $61.98 \mathrm{sec}$ RT was recorded for Saanen bucks, whereas it was $34.25 \mathrm{sec}$ for Nubian bucks (Kamal et al., 2005). Conversely, Darwish and Mahboub (2011) demonstrated that Egyptian-Nubian and Damascus bucks had longer reaction times (1.34 vs $3.82 \mathrm{~min}$, respectively), which are in agreement with the present study. This discrepancy may result from differences in the methods of calculating reaction time, i.e., calculation of the RT during semen collection in restrained animals.

It was reported that testosterone concentration is directly correlated with scrotal circumference (Aller et al., 2012; Mahmoud, 2013; Maksimovic et al., 2016), which is in line with the present study. Ford et al. (2009) demonstrated that there was significant correlation between scrotal circumference and RT in bucks, whereas no significant correlations were present between TC and sexual performance test traits in the present study (Table 3). Previous studies reported that there were significant correlations between testosterone concentration and copulating behavior, such as $n M$ with no ejaculation $(r=0.77)$ (Mahmoud, 2013), RT $(\mathrm{r}=-0.54)$ (Karaca et al., 2015), and courtship behavior, such as naso-genital investigation (Borg et al., 1992).

Mellado et al. (2000) reported that bucks lost $574 \mathrm{~g} /$ day under range conditions during the mating season. Also, it was noted that live weight loss was $143 \mathrm{~g}$ /day in the first cycle of the mating season (Gizaw and Thwaites, 1997). In present study, the higher percentage of live weight loss in SE bucks compared with SI bucks (388 $\pm 9.1 \mathrm{~g} /$ day vs $110 \pm 15.1 \mathrm{~g} /$ day) could be attributed to high sexual activity of SE bucks $(\mathrm{P}<0.001)$ (Table 3$)$. Although no differences were determined in copulation behaviors between SE and SI bucks during sexual performance tests (Table 5), the weight losses determined in SE bucks could be attributed to mating activities. Preston et al. (2012) reported that the time spent searching for receptive females increases in parallel with age in rams. We observed that during the mating period, SE bucks continually engaged in mating activities, dominating and not allowing younger bucks to mate.

As was expected, SE bucks had significantly higher TC than SI bucks $(\mathrm{P}<0.001)$. Similar findings reported that older rams had higher testosterone concentrations than younger ones (Preston et al., 2012; Mahmoud, 2013). Furthermore, the effects of sampling day and time on TC were insignificant (Figure 3).

The findings of the sexual performance test in the present study could suggest that SI bucks were as sexually active as SE bucks. Sexually inactive bucks had higher FR than SE and this might be attributed to lack of experience in identifying the reproductive status of does. However, Darwish and Mahboub (2011) reported that inexperienced bucks had higher latency to anogenital sniffing and RT than experienced bucks. Kridli and Said (1999) reported that yearling lambs exhibited higher $\mathrm{nM}$ and leg-kicking bouts than two-year-old rams, while the ejaculation rates were not different between age groups. Similar findings were also reported by some other researchers (Price et al., 1991; Simitzis et al., 2006). By contrast, Santos et al. (2006) observed that young bucks had shorter RT than older bucks in Alpine and Saanen goats.

In summary, findings of this study demonstrated that an important portion of young bucks were sexually inactive and sexual performance tests did not improve the expression of sexual behaviors. Although serum testosterone concentration was not correlated with sexual behavior, there was a significant difference between active and inactive young bucks in terms of average serum testosterone concentration. However, it should be noted that sexual performance alone is not enough for effective fertility without good quality semen. Thus, without having semen data it is hard to establish a reliable relationship between sexual behaviors and hormonal status in bucks.

\section{Conclusions}

It can be suggested that serum testosterone concentration affects sexual activity in young bucks during the mating season. Additionally, live weight loss can be related with sexual activity during the mating season. On the other hand, the finding that active young bucks and adult bucks had similar ejaculation efficiency and reaction time could be an indication that age-related sexual experience is not related to sexual performance in bucks.

\section{Acknowledgments}

The authors would like to thank Mr. Mehmet Firat (Department of Biology, Yuzuncu Yil University, Van, Turkey) for identifying the species existing in the pasture.

\section{References}

Anonymous. 2016. Turkish State Meteorological Service. Official statistics for meteorological parameters of cities. Available at: $<$ http://www.mgm.gov.tr/veridegerlendirme/il-ve-ilceler-istatistik. aspx?m=VAN $>$. Accessed on: Mar. 28, 2016.

Ahmad, N. and Noakes, D. E. 1995. Seasonal variations in testis size, libido and plasma testosterone concentrations in British goats. Animal Science 61:553-559. 
Al-Ghalban, A. M.; Tabbaa, M. J. and Kridli, R. T. 2004. Factors affecting semen characteristics and scrotal circumference in Damascus bucks. Small Ruminant Research 53:141-149.

Aller, J. F.; Aguilar, D.; Vera, T.; Almeida, G. P. and Alberio, R. H. 2012. Seasonal variation in sexual behavior, plasma testosterone and semen characteristics of Argentine Pampinta and Corriedale rams. Spanish Journal of Agricultural Research 10:345-352.

Borg, K. E.; Esbenshade, K. L.; Johnson, B. H.; Lunstra, D. D. and Ford, J. J. 1992. Effects of sexual experience, season, and mating stimuli on endocrine concentrations in the adult ram. Hormones and Behavior 26:87-109.

Darwish, R. A. and Mahboub, H. D. H. 2011. Breed and experience effect on the sexual behaviors of Damascus and Egyptian-Nubian goat bucks. Theriogenology 76:1386-1392.

Dufour, J. J.; Fahmy, M. H. and Minvielle, F. 1984. Seasonal changes in breeding activity, testicular size, testosterone concentration and seminal characteristics in rams with long or short breeding season. Journal of Animal Science 58:416-422.

Flores, J. A.; Véliz, F. G.; Pérez-Villanueva, J. A.; Martínez de la Escalera, G.; Chemineau, P.; Poindron, P.; Malpaux, B. and Delgadillo, J. A. 2000. Male reproductive condition is the limiting factor of efficiency in the male effect during seasonal anestrus in female goats. Biology of Reproduction 62:1409-1414.

Ford, D.; Okere, C. and Bolden-Tiller, O. 2009. Libido test score, body conformation and testicular traits in Boer and Kiko goat bucks. Journal of Agricultural and Biological Science 4:54-61.

Gizaw, S. and Thwaites, C. J. 1997. Changes in liveweight, body condition and scrotal circumference and their relationships with sexual activity and flock fertility in Ethiopian Horro rams over a 3-cycle joining period. The Journal of Agricultural Science 128:117-121.

Illius, A. W.; Haynes, N. B.; Purvis, K. and Lamming, G. E. 1976. Plasma concentrations of testosterone in the developing ram in different social environments. Journal of Reproduction and Fertility 48:17-24.

Imwalle, D. B. and Katz, L. S. 2004. Development of sexual behavior over several serving capacity tests in male goats. Applied Animal Behaviour Science 89:315-319.

Kamal, A.; Gubartallah, A.; Amel, A.; Bakhiet, O. and Babiker, A. 2005. Comparative studies on reproductive performance of Nubian and Saanen bucks under the climatic conditions of Khartoum. Journal of Animal and Veterinary Advances 4:942-944.

Karaca, S.; Erdoğan, S. and Y1lmaz, A. 2015. The relationship between sexual behaviors and serum testosterone concentrations in Norduz rams. Journal of Animal Production 56:8-13.

Kishk, W. H. 2008. Interrelationship between ram plasma testosterone level and some semen characteristics. Slovak Journal of Animal Science 41:67-71.

Kridli, R. T. and Said, S. I. 1999. Libido testing and the effect of exposing sexually naive Awassi rams to estrous ewes on sexual performance. Small Ruminant Research 32:149-152.

Mahmoud, G. B. 2013. Sexual behaviour, testosterone concentration, semen characteristics and testes size of Ossimi rams as affected by age and scrotal circumference. Egyptian Journal of Animal Production 50:53-58.

Maksimovic, N.; Hristov, S.; Stankovic, B.; Petrovic, M. P.; Mekic, C.; Ruzic-Muslic, D. and Caro-Petrovic, V. 2016. Investigation of serum testosterone level, scrotal circumference, body mass, semen characteristics, and their correlations in developing MIS lambs. Turkish Journal of Veterinary and Animal Sciences 40:53-59.
Mellado, M.; Cárdenas, C. and Ruíz, F. 2000. Mating behavior of bucks and does in goat operations under range conditions. Applied Animal Behaviour Science 67:89-96.

Miranda-de la Lama, G. C. and Mattiello, S. 2010. The importance of social behaviour for goat welfare in livestock farming. Small Ruminant Research 90:1-10.

Moghaddam, G.; Mohamad, M. P.; Asadpour, R.; Rafat, S. A. and Jafari-Jozani, R. 2012. Relationship between levels of peripheral blood testosterone, sexual behavior, scrotal circumference and seminal parameters in crossbred rams. Acta Scientiae Veterinariae 40:1049.

Peel, M. C.; Finlayson, B. L. and McMahon, T. A. 2007. Updated world map of the Köppen-Geiger climate classification. Hydrology and Earth System Sciences 11:1633-1644.

Perkins, A.; Fitzgerald, J. A. and Price, E. O. 1992. Luteinizing hormone and testosterone response of sexually active and inactive rams. Journal of Animal Science 70:2086-2093.

Perkins, A. and Roselli, C. E. 2007. The ram as a model for behavioral neuroendocrinology, hormones and behavior. Hormones and Behavior 52:70-77.

Preston, B. T.; Stevenson, I. R.; Lincoln, G. A.; Monfort, S. L.; Pilkington, J. G. and Wilson, K. 2012. Testes size, testosterone production and reproductive behaviour in a natural mammalian mating system. Journal of Animal Ecology 81:296-305.

Price, E. O.; Estep, D. Q.; Wallach, S. J. and Dally, M. R. 1991. Sexual performance of rams as determined by maturation and sexual experience. Journal of Animal Science 69:1047-1052.

Price, E. O. 1993. Practical considerations in the measurement of sexual behavior. p.16-31. In: Methods in neurosciences. Conn, P. M., ed. Paradigims for study of behavior. Academic Press, California, USA.

Price, E. O.; Borgwardt, R., Blackshaw, J. K.; Blackshaw, A.; Dally, M. R. and Erhard, H. 1994. Effect of early experience on the sexual performance of yearling rams. Applied Animal Behaviour Science 42:41-48.

Price, E. O.; Borgwardt, R. and Orihuela, A. 1998. Early sexual experience fails to enhance sexual performance in male goats. Journal of Animal Science 76:718-720.

Rekik, M.; Salem, I. B. and Lassoued, N. 2012. Reproductive efficiency for increased meat production in goats. p.119-153. In: Goat meat production and quality. Mahgoub, O.; Kadim, I. T. and Webb, E. C., eds. CABI, Cambridge, USA.

Roselli, C. E.; Stormshak, F.; Stellflug, J. N. and Resko, J. A. 2002. Relationship of serum testosterone concentrations to mate preferences in rams. Biology of Reproduction 67:263-268.

Santos, A. D. F.; Torres, C. A. A.; Fonseca, J. F.; Borges, A. M.; Costa, E. P.; Guimarães, J. D. and Rovay, H. 2006. Parâmetros reprodutivos de bodes submetidos ao manejo de fotoperíodo artificial. Revista Brasileira de Zootecnia 35:1926-1933.

Simitzis, P. E.; Deligeorgis, S. G. and Bizelis, J. A. 2006. Effect of breed and age on sexual behaviour of rams. Theriogenology 65:1480-1491.

Snowder, G. D.; Stellflug, J. N. and Van Vleck, L. D. 2002. Heritability and repeatability of sexual performance scores of rams. Journal of Animal Science 80:1508-1511.

Souri, M. and Mirmahmoudi, R. 2014. Effect of season on dry matter intake and reproductive activity of Merghoz buck goats in West of Iran. Iranian Journal of Applied Animal Science 4:317-323.

Stellflug, J. N. and Berardinelli, J. G. 2002. Ram mating behavior after long-term selection for reproductive rate in Rambouillet ewes. Journal of Animal Science 80:2588-2593. 